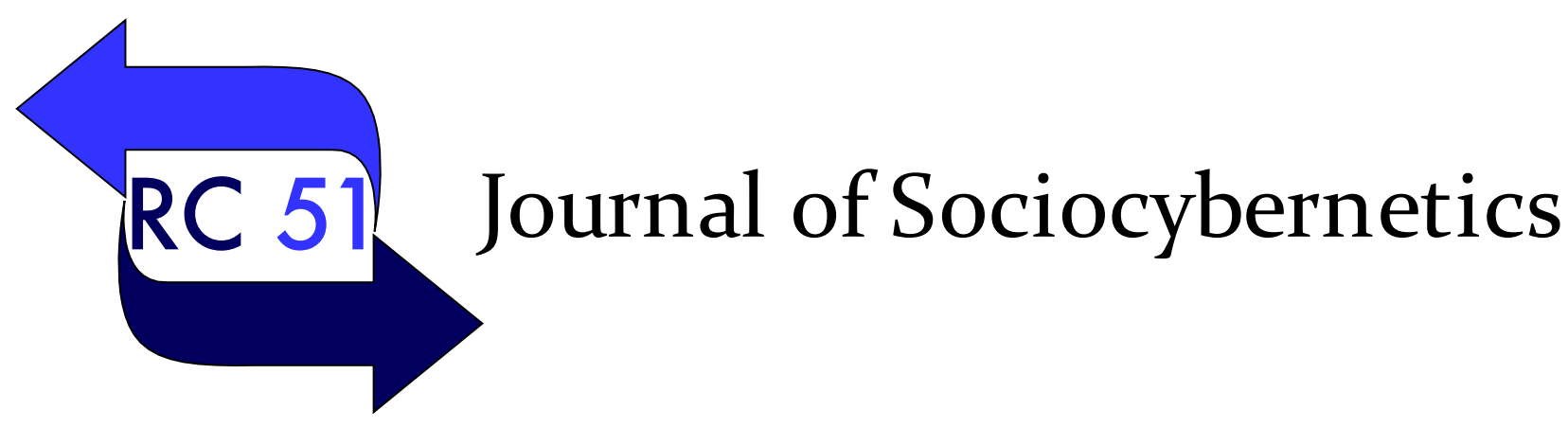

Journal of Sociocybernetics ISSN 1607-86667

\title{
Critical Sociocybernetics: Developing the Concept of Dispositif for an Analysis of Steering Processes Between Social Systems
}

\author{
Juan Carlos Barrón Pastor and Jorge Cardiel Herrera \\ National Autonomous University of Mexico
}

\begin{abstract}
Sociocybernetics is particularly interested in investigating how societies steer their social systems. According to Hornung (2006), sociocybernetic studies have predominantly followed three main strategies: a problem-solution scheme, a structural analysis and a normative proposal. We consider that, to have an integral constructivist foundation, sociocybernetics needs to also take a critical perspective into account. Critical theory used to be circumscribed to the first school of Frankfurt, but now it includes a wide range of approaches —such as Michel Foucault's genealogical and archaeological project, psychoanalytical perspectives (e.g. Slavoj Žižek), schizoidanalysis (e.g. Gilles Deleuze and Felix Guattari), feminist perspectives (e.g. Judith Butler), and de-colonialist proposals (e.g. Boaventura De Sousa Santos)_ offering very diverse notions of power, ethics and transformation. Nevertheless, some key concepts, such as dispositif, event, subject, cultural industry and antagonism, link many of these critical theorists. In this article, we explore how sociocybernetics can develop a critical perspective and some of the challenges of bringing together concepts pertaining to different theories. Specifically, we develop the concept of dispositif originally used by Foucault, Agamben and Deleuze for an analysis of asymmetrical dynamics of power and steering processes between social systems. Thus, we put forth a sociocybernetical understanding of dispositifs as second-order steering mechanisms which intervene strategically between systems and couple them conditionally. Ultimately, we seek to demonstrate that sociocybernetics can benefit from critical theory and vice versa.
\end{abstract}

url:

\section{Introduction.}

Sociocybernetics is particularly interested in investigating how societies steer their social systems (Geyer, 1995). The problem of steering is addressed in cybernetics as a study of control mechanisms (Wiener, 1948). Complexity studies and systems theory also have a wide range of developments concerning this issue. Nonetheless, as already acknowledged by Von Foerster in Cybernetics of Cybernetics, a constructivist basis is defined in sociocybernetic approaches (2003).

Complexity studies can be divided into two general approaches, as identified by Díaz Mata (2012): a) sciences of complexity offer exhaustive descriptions identifying multiple, interconnected variables, even though many times they do not depart from a constructivist approach but from a positivist one, and; b) authors such as Morin and Capra, labelled by Díaz Mata as 'universalists' offer explanations

Corresponding author: Juan Carlos Barrón Pastor; e-mail: juancho_barron@yahoo.com 
that attempt to not fragment the world and defy disciplinary boundaries, intending to re-think transdisciplinarily every aspect of the world.

General systems theory's applications to social sciences are also diverse. Two of the most prominent proposals in the 2oth century were Talcott Parsons' social system theory (1951) and Niklas Luhmann's social systems theory (1984). Both authors are particularly exhaustive in describing how social systems perform. In contrast, sociocybernetics aims not only to describe elements or interactions of social systems but to reflect on the steering processes in which they take part.

Generally, attempts to explain how social systems are driven tend to naturalize steering itself, perhaps because of Maturana and Varela's proposals (1996) to introduce certain explanations from biology into social systems. Also, Luhmann's (1996) universal inferences, and his usage of some key concepts such as self-organization, operational closure, or interpenetration, might have helped cultivate the idea that social systems operate "naturally". In order for sociocybernetics to be reflexive and self-reflexive, it is important to keep in mind that social systems are being constructed. Steering systems are also social constructs, hence their behaviour is not determined by natural (selfregulating) forces only.

Critical theory used to be attached to the first school of Frankfurt, but now it includes a wide range of approaches — such as Michel Foucault's genealogical and archaeological project, psychoanalytical perspectives (e.g. Slavoj Žižek), schizoid-analysis (e.g. Gilles Deleuze and Félix Guattari), feminist perspectives (e.g. Judith Butler), and de-colonialist thinkers (e.g. Boaventura De Sousa Santos)— offering very diverse notions of power, ethics and transformation. For Macey (2000: 74) critical theory refers to "a whole range of theories which take a critical view of society and the human sciences or which seek to explain the emergence of their objects of knowledge". Geuss (1981) explains that Critical Theory is inherently emancipatory, has a cognitive content, is self-conscious, self-critical and non-objectifying. Wiggershaus (1986) considers the postulate that society is a whole with inner antagonistic elements as its key element. How (2003) remembers the Marxist and Hegelian roots of critical theory and the importance of dialectics. For him, critical theory uses speculation not as a pejorative notion, but as a reflection that needs a kind of mirror (speculum).

Critical theory offers very diverse notions of power, ethics and transformation. Almost one hundred years of critical theory are impossible to resume for the aims of this article. However, some key concepts — such as dispositif, event, subject, cultural industry and antagonism - link many of the authors we just mentioned. One of these key concepts in contemporary critical theory is "dispositif". It was originally used by Michel Foucault. From a sociocybernetic perspective, we argue that it can be understood as a steering mechanism.

According to Hornung (2006), sociocybernetic studies have followed three main strategies to understand how do social systems direct their efforts to keep a specific social system functioning: 1) a problem-solution perspective, usually proposing practical models to explain how a certain social system solves a problem, 2) a structural perspective, which typically depicts hierarchical structures by describing systems, subsystems and interphases, and 3) a normative perspective, which identifies adaptation guidelines for social systems.

A far-reaching history of cybernetics has many references to power: Wiener, Bateson, von Foerster, Pask, Maturana, and Scott, among others. They all have had receptive insights from authors that could be broadly considered as part of critical theories' tradition; such as Freire's critical pedagogy or Pablo Martin-Baro's liberation psychology. Even though, the Research Committee 51 on Sociocybernetics might not been sufficiently perceived among its pairs at the International 
Sociological Association (ISA) as using critical theories, beyond the boundaries of internal discussions.

However, in the last decade, several works (e.g. González, Maass, Amozurrutia, and AlmaguerKalixto) have offered powerful insights developed within the proposal of Cybercultur@ to the Research Committee on Sociocybernetics. Their purpose is not only to explain, but also to ethically steer social intervention. Within this perspective, Amozurrutia proposed a heuristic method to uniform investigative strategies of research teams, based on learning processes of social systems in which researchers are involved.

Like Gonzalez Casanova (2004) explained, complexity and social systems theories are already in the process of being captured by hegemonic forces. For him, it is necessary to develop not only the concepts, the methods and the epistemological stances proposed by major thinkers such as Rolando García (2006) for interdisciplinary research targeting to explain social systems. It is also essential to develop political theories utilizing such tools, but recognizing that social systems' adaptation and survival might depend on recovering them from the actors that have captured them in the past, particularly in the last quarter of the century.

During the past five years, Juan Carlos Barrón has introduced at ISA and $\mathrm{RC}_{51}$ Sociocybernetics conferences the idea that sociocybernetics can benefit from critical theory and vice versa, suggesting to link some aspects of sociocybernetics to key concepts of critical theory. This epistemological stance will have a first example and application that will be published this year. Critical sociocybernetics pretends to offer, from a constructivist paradigm, a philosophical epistemological, ethical, political - proposal, seeking to deliver a point of departure to social research aiming to explain, anticipate, and transform ethically the steering of social systems.

In this article, we explore how sociocybernetics can develop a critical perspective, and some of the challenges of bringing together concepts pertaining to different theories, that imply different approaches. We develop the concept of "dispositif" originally used by Foucault, Agamben and Deleuze for a sociocybernetical analysis of asymmetrical dynamics of power and steering processes between social systems. We understand dispositifs as second-order steering-mechanisms, which intervene strategically between systems and couple them conditionally.

\section{Dispositifs as Steering Mechanisms}

"Dispositif" is a key concept used by many contemporary critical-theorists. Currently, there is a theoretical and etymological debate regarding the concept (see Raffnsøe, Gudmand-Høyer and Thaning 2014; Pasquinelli 2015). Although Michel Foucault's usage is the most common, it has been redirected into alternate realizations of its potentialities. To contain its conceptual vastness, in this article we focus on two derivative treatments of the dispositif: the Deleuzian and the Agambian. Qu'est-ce qu'un dispositif? by Deleuze was published in 1988, and Che cos'è un dispositivo? by Agamben was published in 2006. Both essays address the same concept and their titles are identical. However, in English they were translated as What is a dispositif? (1992) and What is an apparatus? (2009), respectively.

Here we encounter the vicissitudes of translating a concept which has an etymology belonging to the Romance languages. Like Agamben, we believe terminological questions are important. In this article, we use the original term "dispositif" as it appears in the writings of Michel Foucault to avoid confusion with other words such as "apparatus", "device" or "deployment", which have been used in the English translations of Foucault as alternatives to "dispositif". In addition, we maintain a distinction between "dispositif" and "apparatus", following Foucault's differentiated use of the French words "dispositif" and "appareil” in Histoire de la sexualité 1: La volonté de savoir. In a single 
paragraph, for example, we can read about "les appareils du pouvoir" and "les dispositifs de la domination" (Foucault, 1976: 89). In contrast, the English version translates these two concepts varyingly as "devices", "apparatus" and "deployment".

Before undertaking the analysis of the conceptual nuances of the word "dispositif", it is necessary to understand some of its common meanings in Romance languages. Agamben cites three meanings from common French dictionaries (Agamben, 2009: 7):

a. A strictly juridical sense: "Apparatus is the part of a judgment that contains the decision separate from the opinion". That is, the section of a sentence that decides, or the enacting clause of a law.

b. A technological meaning: "The way in which the parts of a machine or of a mechanism and, by extension, the mechanism itself are arranged".

c. A military use: "The set of means arranged in conformity with a plan".

We can add two uses of the word "dispositivo" in Spanish: a) A word to indicate all kinds of artifacts, as in the English term "device", and b) A police operation involving placing barricades and deploying antiriot police officers, as in the case of a protest or mass event.

In English, there is "disposition", which is very close in meaning to the definition given by Agamben. Also, it shares the ending with the Latin word dispositio, which can be traced as a predecessor of "dispositivo" or "dispositif". Agamben himself uses the term "dispositor" as a translation of "dispositif", an astrological term which "embodies all of the forces and influences that the planet exerts on individuals, inclining them, binding them and restraining them in all possible ways" (2005). With the hope of not adding more ambiguity to the existing debate about the translation of this term, we prefer for this paper to use the original Foucaultian word.

\section{Dispositif in Foucault and Agamben}

Revising some of Foucault's texts $(1978 ; 1995)$, we encounter that he doesn't give a concluding definition of what a dispositif is. But there is a long excerpt in an interview from 1977, in which he enlists many characteristics of the dispositif, which Agamben also cites:

What I'm trying to single out with this term is, first and foremost, a thoroughly heterogeneous set consisting of discourses, institutions, architectural forms, regulatory decisions, laws, administrative measures, scientific statements, philosophical, moral and philanthropic propositions-in short, the said as much as the unsaid. Such are the elements of the apparatus (dispositif). The apparatus (dispositif) itself is the network that can be established between these elements [...] By the term "apparatus" (dispositif) I mean a kind of a formation, so to speak, that a given historical moment has as its major function the response to an urgency. The apparatus (dispositif) therefore has a dominant strategic function [...] I said that the nature of an apparatus (dispositif) is essentially strategic, which means that we are speaking about a certain manipulation of relations of forces, of a rational and concrete intervention in the relations of forces, either so as to develop them in a particular direction, or to block them, to stabilize them, and to utilize them. The apparatus (dispositif) is precisely this: a set of strategies of the relations of forces supporting, and supported by, certain types of knowledge (Foucault 1980: 194-196).

Analyzing this citation, we obtain at least six features belonging to the sociopolitical formation Foucault calls the dispositif:

1. Heterogeneity: this formation includes all kinds of elements, linguistic and nonlinguistic.

2. Relationality: it is a network between the included elements. 
3. An aim to respond to an urgent need: its historical emergence responds to an urgent social problem.

4. Instrumentality: the dispositif is a mechanism or device made to obtain a pursued outcome.

5. A dominant strategic function: the dispositif effects a certain manipulation of relations of forces, "either so as to develop them in a particular direction, or to block them, to stabilize them, and to utilize them" (Foucault 1980: 194-196).

6. Interdependency with knowledge: the dispositif is "a set of strategies of the relations of forces supporting, and supported by, certain types of knowledge" (Foucault 1980: 194-196).

Departing from Foucault's exposition and usage in his works, and drawing on his own research on oikonomia, Agamben expands the conceptual scope of the notion of dispositif. A paradigmatical example of a dispositif that relies on an artifact (a building) is the panopticon, as featured in Foucault's research. An example of a dispositif operating in the symbolical domain is sexuality, which Foucault also analyzes. In addition, Agamben mentions a large list of tools and machines which are also dispositifs (2009). His proposal is to conceive ontologically the distinction between living beings (or substances) and dispositifs. In his view, the dispositifs are a large class that accompanies Homo sapiens since his appearance in the world. In contemporary society, he claims, there is a massive accumulation and proliferation of dispositifs (Agamben 2009: 15). In his essay What is an Apparatus? he proposes a definition and makes a list of existing dispositifs, notably including language as one of them (Agamben 2009: 14).

Further expanding the already large class of Foucauldian apparatuses (dispositifs), I shall call an apparatus (dispositif) literally anything that has in some way the capacity to capture, orient, determine, intercept, model, control, or secure the gestures, behaviors, opinions, or discourses of living beings. Not only, therefore, prisons, madhouses, the panopticon, schools, confession, factories, disciplines, juridical measures, and so forth [...], but also the pen, writing, literature, philosophy, agriculture, cigarettes, navigation, computers, cellular telephones and — why not- language itself $[\ldots]$.

Referring to the processes of subjectification correlating with the emergence of each dispositif, Agamben points out two other important features of the dispositif that constitute it not only as a sociopolitical formation, but also as a psychopolitical one:

7. Internalization of the dispositif or subjectification: "Every apparatus (dispositif) implies a process of subjectification, without which it cannot function as an apparatus (dispositif) of governance, but is rather reduced to a mere exercise of violence" (Agamben 2009: 19).

8. The capture of desire: "At the root of each apparatus (dispositif) lies an all-too-human desire for happiness. The capture and subjectification of this desire in a separate sphere constitutes the specific power of the apparatus (dispositif)" (Agamben 2009: 17).

Dispositifs in the Fields of Power

Theories of social systems, such as those developed by Talcott Parsons and Niklas Luhmann, tend to deal heavily with universal macro-systems differentiated in specific functions. But, facing the events occurring in contemporary societies, it is insufficient to consider only "the universals" - as Foucault calls those all-encompassing categories like the State, Law, and Power- for a vast analysis of sociopolitical reality.

One of the aims of Foucault's works is to investigate how power is exercised at its most concrete level. We do not intend to deny the existence of social macro-systems, like Art, Science, Economy 
and Politics. Moreover, what the dispositif can make visible is the complex organization of power relationships occurring at the meso and micro levels of intersection between all types of systems (psychical, social, biological and technological). Analyzing dispositifs is useful to think about technologies and techniques of power in an immanent historical and sociopolitical dimension. Because the dispositif is always caught in a historical state of power relations, it cannot be naturalized or conceived only in a neutral or instrumental way.

To be in a suitable position for questioning how a dispositif works, it is required to put forward a view on the relationship between power and societies. "Relationality" has already been mentioned as one of the features of the dispositif, now it is necessary to clarify what will be meant when speaking about power relations within social formations. First, it is obliged to ask: How is it possible to think social relations? And then: How to conceive power? Contemporary available sociological and political theories have a wide range of different answers. From a critical-theoretical perspective, it is fundamental to bear in mind two postulates: a) That each answer leads the thinker to locate himself in certain positions within the field of power, excluding other possible positions he could create or subscribe to. Discourses are a research resource for sociopolitical analysis, yet the analyzer also produces a specific discourse, when he communicates his observations. The analyzer, as every second-order observer, comes up with discourse acts from a specific point of view, and conceives power and the social in a specific way; b) Because power is omnipresent, one cannot formulate the question concerning social relations without already having an implicit theory of power and vice versa. As Bernard Scott puts it: "One cannot not have an agenda" (2006:308-316).

This is the place where some sociological system theories bring forth a distinction between the social and the political using an analytical dispositif. One example is Niklas Luhmann's social systems theory that proposes that society is communication and nothing more than that. This conception is circular and excludes everything other than communication as part of the milieu (Luhmann 2001: 111). If one follows this path, two consequences result:

1) Power appears as a symbolic generalized medium of communication among others like money, faith, love, art and trust. Even though Luhmann admits its universal character, he relates power fundamentally to the code of the political system, which operates with the guiding distinction between government/opposition. It is not clear in his theory how power functions in the whole of society and its role in the structural coupling between social systems.

2) Politics appear like a subsystem within the supersystem of society, among other subsystems like science, art, law and economy.

Unlike Luhmann, we believe the question about the social relation is not yet answered when replaced with an entity called communication that explains itself. From Luhmann's analytical point of view, each system is operationally closed. That is why he focuses in describing how every subsystem operates, and when he builds a general theory of society, the problem of the articulation between the subsystems is addressed with the concept of structural coupling.

We propose a widened concept of dispositif for the analysis of social phenomena, and show how it works by examining how particular dispositifs can grow its steering power and exercise it in relation to other social and psychic formations. We observe that the concepts of structural coupling, irritation or interpenetration — as developed by Luhmann for the field of sociology - are not able to describe entirely what happens at the compositional level of social systems. Even though Luhmann defines power as a "social universal" (2005), he emphasizes power as the code of the political system, and focuses on isolating each correspondent code for each other social subsystem. This analytical 
endeavour is productive when comparing the internal functioning of systems, but it is not able to observe the interrelation between attempts of steering and social conflicts.

Critical sociocybernetics observes that steering is possible only because of the existence of psychosocial formations called "dispositifs" that exercise power, as Foucault also recognizes. If, within the context of a strong sociological theory, power is to be understood as a social universal, one should explain how it also takes part at the level of the interrelations between systems. Our main thesis is that the media of structural coupling are occupied by dispositifs that establish relations of power between social systems and the psyche. Therefore, we propose an understanding of the dispositif as a second-order formation that relies on other existing formations like institutions, media and social movements. The dispositif doesn't directly steer humans or other social formations, but is used to intervene strategically at the level of structural couplings between systems. From this perspective, conflicts between social systems or between subjects occur not only in the event of systemic de-differentiation, but also as an expression of the relations of force in the interplay between systems and subjects and as a resistance to the governance of the dispositifs. This argument, we understand will need a deeper insight in relation to the metaphors of force widely used in sociocybernetics, but it will be an issue for a further text. As a disclaimer, we would differentiate relations of force as a possibility within the field of power.

From the perspective of critical theory, social relations are always political. Every human act is discursive and involves the formation or modification of relations of force. Through an exercise of power, both institutions and dispositifs establish relations of force. The dominant strategic function of the dispositif is either to maintain or to modify the existent state of the relations of force within the field of power. Dispositifs use signs, communications, bodies, thoughts and artifacts to organise these relations of force. Discourses are semiotic dispositifs.

The autonomy of social formations - like systems and institutions - is always relative, because it is referred to other social formations in a field of power. Social relations only appear by looking at the positions in a field of power, constantly implied in mediating dispositifs and in discourses that redefine them. In these conditions, a subject capable of political action emerges.

Fig. 1 is a diagram of how positions within a field of power are supported by social relations. At the same time, these positions are produced performatively through discourses. Social relations rely on institutions like language, work, education, science, media and art. These institutions are linked to a huge variety of dispositifs like the computer, the fabric, machines, the school, the laboratory, radio, internet, discourses, a gallery or a museum. And as one of the reviewers highlighted, these items only become 'dispositifs' by virtue of their place in a network of relations distinguished by an observer. When a human subject speaks, her/his utterance is modulated by the institutions, by the dispositifs (s)he takes part in, by the position from which (s)he speaks and by other utterances. Subjects like the student, the worker and the radio listener only emerge with the institutions and the dispositifs that make them possible. 


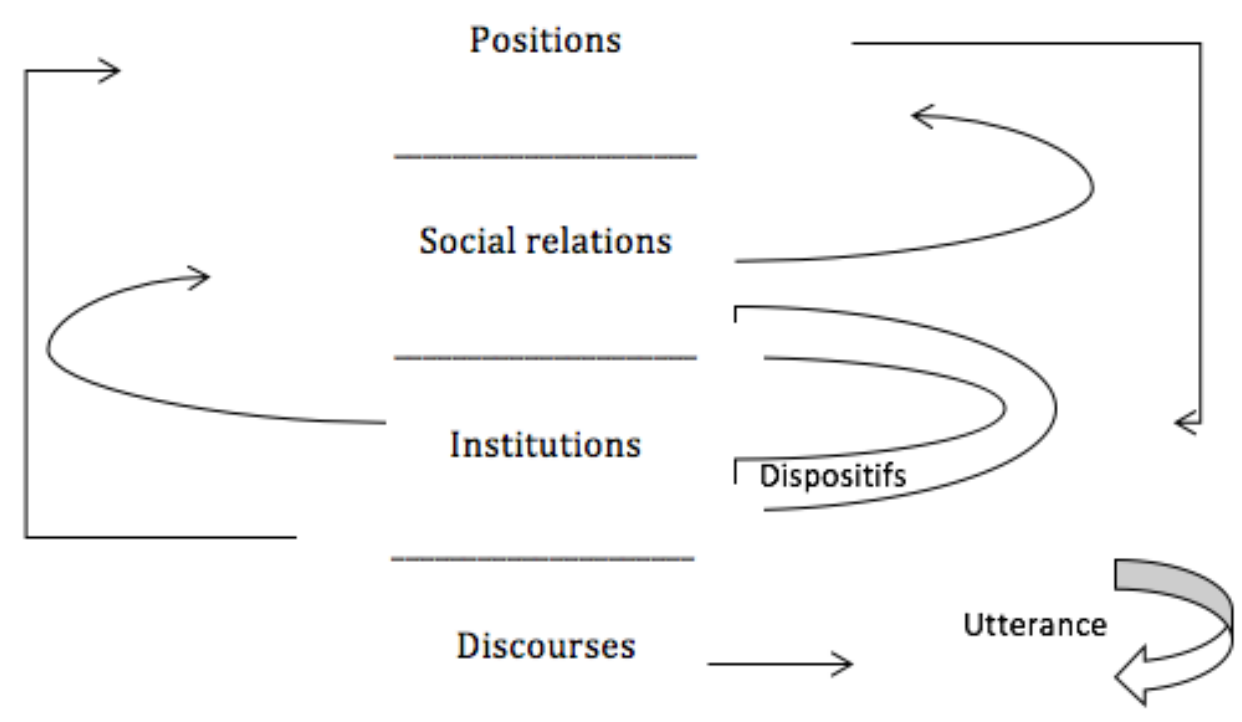

Figure 1. The field of power.

By developing a sociocybernetic concept of dispositif, some of the research questions that arise are the following: $i$ Which elements are reunited by the dispositif? $¿$ How are they networked? $i$ To what urgent need the dispositif aims to respond? ¿Which outcome does the dispositif pursue? ¿Which communications does it enable and which possibilities does it obstruct? $¿$ On which other dispositifs or systems it relies? ¿On which types of knowledge does it rely? ¿Which discourses does it support? ¿Which processes of subjectification emerge? ¿Which subjects it produces?

\section{Conclusions}

At this point we can clearly see the challenges we went through developing a concept from critical theory for a sociocybernetic understanding of power dynamics and steering processes. As it can be inferred from Arendt's epigram to this article, power and violence are problematic notions. For her, power is the human ability to act in concert towards certain political goals. For Marcuse (1953) power does not come from above to the ground; instead, our psychological problems become political and societal through different processes explained by Freud such as transference and denial. For Guattari (2011), power as social control delivers the dispositifs that protect people from their own desires (of power). Butler (2001) considers that the subordination of the subject is produced as regulative power (violence, in Arendt's terms) that reproduce the requirements of continuity, visibility and localization of those subjects to be considered as powerful (agents of violence, to be accurate). Subjects, however would follow melancholic psychological mechanisms, as those pointed by Marcuse to produce the limits of that subjectification, creating a potential power that could resist and oppose the violence coming from above, from the actors that have appropriated the rights to exert violence to benefit their interests of their dominance and prevalence. According to Marcuse and Guattari, the interiorization of submissive mechanisms through dispositifs play an important role in the normalization of violence.

We affirm that dispositifs can be considered as steering mechanisms; that is why it can be useful for investigations utilising cybernetics' framework. Steering and management are close to the notion of power when it is understood - as Voltaire did — as "the ability of making others act as I choose". Certain actors try to gain power to make others act according to the interests of those "powerful". The innate tendency to persist of every system, the conatus of Spinoza, is the relying assumption that explains the will of every system to produce and reproduce power, exert violence selectively towards certain elements and interactions, and its elements experiment a kind of jouissance for 
constructing both. But can actors working to dismantle the capacities of social systems to adapt and persist can be considered as powerful? Or is it as Arendt stated: they are violent to the social systems and invert the social construction of violence using systemic, symbolic and situational violence (Žižek, 2008; Barrón 2011) to force the capture of the functioning of social systems; and simultaneously, those organised subjects becoming systems as well?

The antagonist and particularized elements proposed by critical theory are accurate when explaining the exercise of power, in contrast to the normative universal proposals that only explain its general functioning. It is important then to continue building on how concepts of critical theory work in a system-theoretical and sociocybernetic framework.

It should be noted that this article only dealt with dispositifs, understood as formations that intervene strategically in the media on which systems rely for their operations. We found that dispositifs exercise power, either by narrowing the amount of forms, patterns, expectations or choices available in those media, or by favoring some of these elements instead of others. As we have seen, there exists a variety of dispositifs operating in contemporary societies. Some of them are directly linked to artifacts and some of them only operate in symbolical, linguistic and communicative domains.

The dispositifs performance standardizes a stock of possibilities into reliable and repeatable information. On the one hand, this helps systems simplify their processing of irritations from the environment and organize their conditional couplings. On the other hand, the dispositif also trivializes the complex relations between system/environment, system/systems and system/medium. Because of standardization and trivialization, the adaptability of social systems and of the psyches is challenged. Sometimes, systemic processes of adaptation are exercised through alternate uses of the dispositif (transgressions or profanations) or even lead to the formation of counter-dispositifs, which are exercises of resistance to power carried out by political actors and social movements. We are proposing to incorporate aspects of critical theory into sociocybernetics, to the enrichment of both. As cybernetics values high order abstractions, it can be considered Foucault's thinking is cybernetic by any other name. Understanding the role of power between social systems, media, political actors and dispositifs will be a task on the long term for critical sociocybernetics.

\section{References}

Agamben, Giorgio. (2005). What is a Dispositor? Lecture transcript by Jason Michael Adams. Accessed on November 29, 2017,

https://eclass.upatras.gr/modules/document/file.php/ARCH213/Agamben\%20Dispositor.pdf

Agamben, Giorgio. (2006). Che cos'è un dispositivo?. Roma: Nottetempo.

Agamben, Giorgio. (2009). «What is an Apparatus?». In What is an Apparatus? and Other Essays. California: Stanford University Press.

Amozurrutia, José. (2011). Complejidad y ciencias sociales: un modelo adaptativo para la investigación interdisciplinaria. Mexico City: CEIICH-UNAM.

Arendt, Hannah. (1970). On Violence. New York: Harcourt Books. 
Barrón Pastor, Juan Carlos. (2011). Theorising intercultural relations: A reflection on cultural identities, violence and emotional affects in Mexico (Doctoral Thesis), School of International Development, University of East Anglia, UK.

Butler, Judith. (2001). Mecanismos psíquicos del poder: Teorías sobre la sujeción. Madrid: Ediciones Cátedra/Universitat de Valencia.

Diaz Mata, Alfredo. (2012). «Tres aproximaciones a la complejidad». In Díaz Mata (Coord.). El enfoque de la complejidad: diversas perspectivas. Mexico City: FCA Publishing/ DGAPA-UNAM.

Deleuze, Gilles. (1988). »Qu'est-ce qu'un dispositif?«. In Michel Foucault philosophe: Rencontre internationale. Paris, 9, 10, 11 janvier 1988. Paris: Seuil.

Deleuze, Gilles. (1992). »What Is a Dispositif?«. In Timothy J. Armstrong (Ed.), Michel Foucault Philosopher. Hemel Hempstead: Harvester Wheatsheaf.

Foucault, Michel. (1976). Histoire de la sexualité I: La volonté de savoir (2013 ed.). Paris: Gallimard.

Foucault, Michel. (1978). The History of Sexuality: Volume 1: An Introduction. New York: Pantheon Books.

Foucault, Michel. (1980). Power/Knowledge: Selected Interviews and Other Writings 1972-1977. New York: Pantheon Books.

Foucault, Michel. (1995). Discipline and Punish: The Birth of the Prison. New York: Vintage Books.

García, Rolando. (2006). Sistemas complejos: Conceptos, método y fundamentación epistemológica de la investigación interdisciplinaria. Barcelona: Gedisa.

Geyer, Felix. (1995). «The Challenge of Sociocybernetics». In Kybernetes, 24 (4), 6-32.

González Casanova, Pablo. (2004). Las nuevas ciencias y las humanidades: De la academia a la política. Mexico City: Anthropos/IIS-UNAM.

Guattari, Felix. (2013). Líneas de fuga: por otro mundo de posibles. Buenos Aires: Cactus occursus.

Hornung, Bernd. (2001). «El paradigma sociocibernético: conceptos para la investigación de sistemas sociales complejos». In Sociocibernética: Lineamientos de un paradigma. Zaragoza: Institución Fernando El Católico.

How, Alan. (2003). Critical Theory. London: Palgrave McMillan.

Luhmann, Niklas. (1984). Soziale Systeme: Grundriß einer allgemeinen Theorie. Frankfurt am Main: Suhrkamp.

Luhmann, Niklas. (1995). Social Systems. Stanford: Stanford University Press.

Luhmann, Niklas. (1996). Introducción a la teoría de los sistemas. Mexico City: Universidad Iberoamericana. 
Luhmann, Niklas. (2001). «Wie ist Bewußtsein an Kommunikation beteiligt?». In Aufsätze und Reden. Stuttgart: Reclam.

Luhmann, Niklas. (2005). Poder. Mexico City: Universidad Iberoamericana/Anthropos.

Macey, David. (200o). Dictionary of Critical Theory. London: Penguin.

Marcuse, Herbert. (1953). Eros y Civilización (2015 ed.). Barcelona: Ariel.

Maturana H. y Varela, F. (1996). El árbol del conocimiento: las bases biológicas del conocimiento humano. Barcelona: Debate.

Scott, Bernard. (2006). «Reflexivity revisited: the sociocybernetics of belief, meaning, truth and power», Kybernetes, 35, 3/4.

Von Foerster, Heinz. (2003). «Cybernetics of Cybernetics». In Understanding Understanding: Essays on Cybernetic and Cognition, New York: Springer.

Wiener, Norbert. (1948). Cybernetics: Or Control and Communication in the Animal and the Machine (2nd ed.). Cambridge: The M.I.T. Press.

Wiggershaus, Rolf. (1986). La escuela de Fráncfort. Mexico City: CFE-UAM.

Žižek, Slavoj. (2008). On violence. London: Verso. 